Primljen / Received: 12.2.2014 Ispravljen / Corrected: 19.5.2014. Prihvaćen / Accepted: 20.6.2014. Dostupno online / Available online: 1.8.2014.

\section{Shaking table study of masonry buildings with reinforced plaster}

Authors:

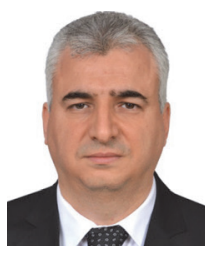

Assist.Prof. Hakan Başaran, PhD. CE

University Celal Bayar

Faculty of Civil Engineering

hakan.basaran@cbu.edu.tr

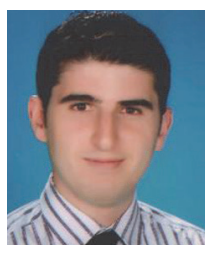

Assist.Prof. Ali Demir, PhD. CE

University Celal Bayar

Faculty of Civil Engineering

ali.demir@cbu.edu.tr

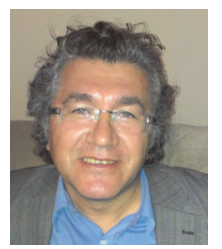

Assoc.Prof. Muhiddin Bağcı, PhD. CE

University Celal Bayar

Faculty of Civil Engineering

muhiddin.bagci@cbu.edu.tr

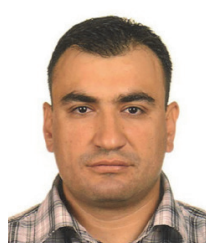

Emre Ercan, PhD. CE

University Ege

Faculty of Civil Engineering

emre.ercan@ege.edu.tr
Scientific paper - Preliminary note

Hakan Bașaran, Ali Demir, Muhiddin Bağcı, Emre Ercan

\section{Shaking table study of masonry buildings with reinforced plaster}

The objective of this study is to determine seismic behaviour of masonry buildings with reinforced plaster mortar, with a particular focus on the modification of structural response due to application of the polypropylene and steel reinforced plaster, as compared to an ordinary type of plaster. The resistance of one-storey single-span masonry buildings subjected to seismic load on the shaking table is investigated in the study. Experimental results revealed natural periods, response acceleration spectrums, and spectrum interactions of masonry buildings. In addition, finite element models of test buildings were established, and their results were compared with those obtained during experimental study.

Key words:

masonry building, reinforced plaster, shaking table, dynamic behaviour

Prethodno priopćenje

Hakan Başaran, Ali Demir, Muhiddin Bağcı, Emre Ercan

\section{Ispitivanje zidanih gradevina s armiranom žbukom na vibracijskom stolu}

U radu je prikazano određivanje seizmičkog ponašanja zidanih građevina sa žbukom od armiranog morta, pri čemu je naglasak stavljen na promjenu odziva konstrukcije kada se umjesto obične žbuke koristi žbuka armirana polipropilenom i čelikom. Na vibracijskom stolu analizirana je otpornost na seizmičko opterećenje jednokatnih, jednorasponskih zidanih građevina. U toku ispitivanja, određeni su prirodni periodi, spektri ubrzanja odziva i spektar ovisnosti zidanih građevina. Za ispitane su građevine izrađeni i modeli metodom konačnih elemenata te su rezultati proračuna uspoređeni s rezultatima ispitivanja.

Ključne riječi:

zidana gradevina, armirana žbuka, vibracijski stol, dinamičko ponašanje

Vorherige Mitteilung

Hakan Bașaran, Ali Demir, Muhiddin Bağcı, Emre Ercan

Prüfung von Mauerwerksbauten mit verstärktem Putzmörtel auf dem Rütteltisch

In dieser Arbeit wird das seismische Verhalten von Mauerwerksbauten mit verstärktem Putzmörtel erforscht, insbesondere der Einfluss durch Polypropylen oder Stahl verstärken Mörtels im Vergleich zu herkömmlichem Putz. Die Widerstandsfähigkeit einstöckiger, einspänniger Mauerwerksbauten gegen seismische Einwirkungen ist auf dem Rütteltisch untersucht. Im Verlauf der Prüfungen sind die Eigenschwingungsperioden, die Antwortspektren der Beschleunigung und deren Bezug zu Antwortspektren der Verschiebung ermittelt worden. Finite-ElementeModelle der Bauwerke sind ebenfalls erstellt, um die Resultate der Analysen mit den experimentellen Werten zu vergleichen.

Schlüsselwörter:

Mauerwerksbauten, verstärkter Putzmörtel, Rütteltisch, dynamisches Verhalten 


\section{Introduction}

Masonry is a construction material that is widely used around the world due to its low cost and ease of construction. Masonry buildings account for about $50 \%$ of all buildings in Turkey. These masonry buildings, especially those built in rural areas, received minimum, if any, service from the engineering profession. Usually, people residing in these buildings are the ones who built them. Consequently, these structures do not comply with appropriate standards specified in Turkish Earthquake Code (2007). In fact, several earthquake disasters in Turkey have revealed that these buildings are not earthquake-safe (Figure 1).

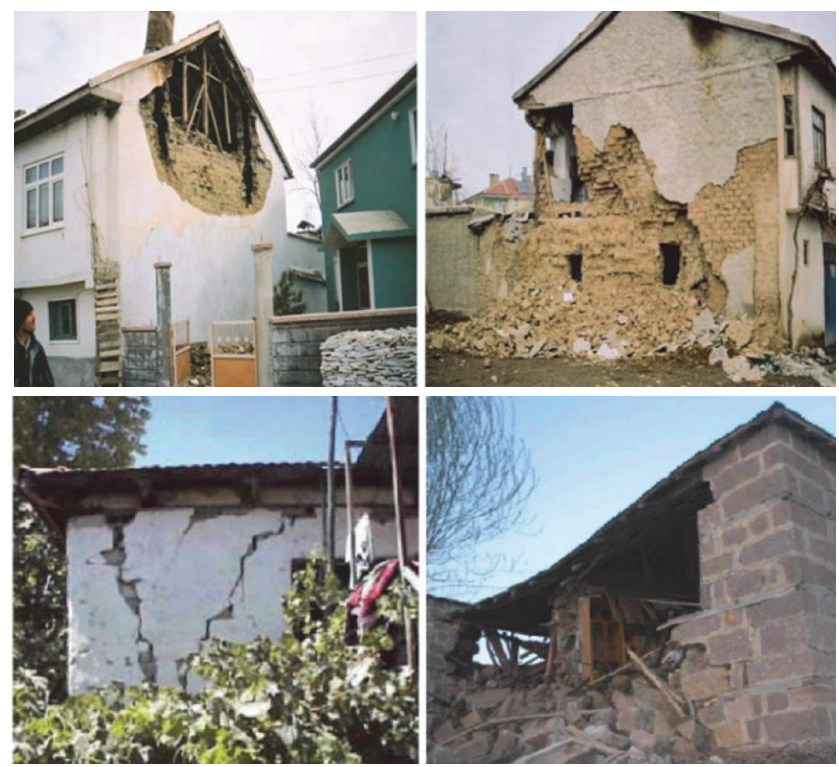

Figure.1 Damage to masonry structures

The vulnerability of masonry structures to seismic load has being recognized a long time ago, and considerable efforts have so far been invested to provide guidelines for the construction of sound earthquake-resistant houses. Despite these praiseworthy endeavours, many casualties due to collapse of masonry houses during earthquakes are reported year after year [1].

In masonry buildings, the loads affecting the system are assumed by inner and outer walls and are then transferred to the base. Therefore, walls are of great significance for masonry buildings. The damage occurring in walls weakens the bearing system of such buildings. Materials used in the construction of masonry buildings, such as stone and brick, are bound to each other by means of mortar with mineral binder. Walls constructed in this way are resistant to vertical loads, but not to horizontal actions. To overcome this weakness, several studies have been conducted with regard to masonry buildings, and retrofitting methods for unreinforced masonry structures have been developed. These retrofitting methods can be classified into two categories. Methods belonging to the first group are aimed at increasing the adherence between the brick and mortar. To accomplish this, several additives have been added to the mortar mix. Thus, the strength, stiffness and ductility of masonry buildings have reportedly been improved [2-16]. On the other hand, methods forming the second group involve the strengthening of brick surfaces using materials such as FRP, wires, fibre materials, steel mesh, steel and wood sheets, and used tires [17-22]. A comprehensive review of such materials is given in the paper proposed by Lizundia et al [23].

The effects of plaster used in masonry buildings are investigated in this study. Specimens of mortars used in the walls of masonry building were reinforced with steel and polypropylene fibres. Three types of $1 / 3$ scaled models of one story single-span masonry buildings were tested under seismic excitations on the shaking table. Mortar specimens with the aforementioned additives exhibited some changes in seismic behaviour.

\section{Materials and methods}

\subsection{Description of specimens}

Three types of $1 / 3$ scaled model masonry structures, with plaster mortar comprising the cement-lime mixture, polypropylene and steel fibres, were constructed. The geometry of the masonry structure built on a shaking table is shown in Figure 2. The masonry building dimensions were scaled taking into account the capacity and power of the shaking table. The masonry structure is $120 \mathrm{~cm} \times 120 \mathrm{~cm}$ in area, the height is $90 \mathrm{~cm}$, and the slab thickness is $5 \mathrm{~cm}$. The masonry wall has lintels measuring $10 \mathrm{~cm} \times 10 \mathrm{~cm}$. Double lined blending filled bricks, $5 \mathrm{~cm}$ in thickness, were used in the walls of the structures.

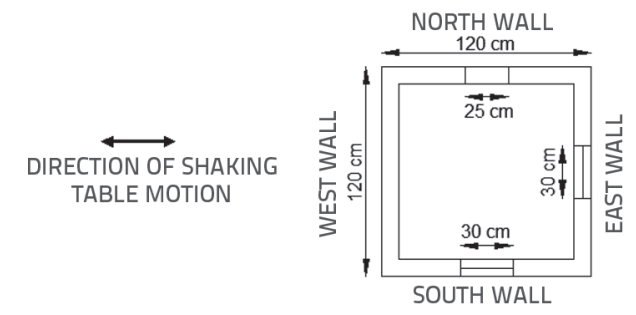

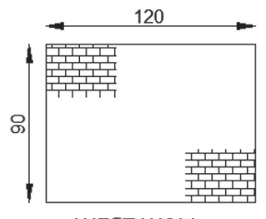

WEST WALL
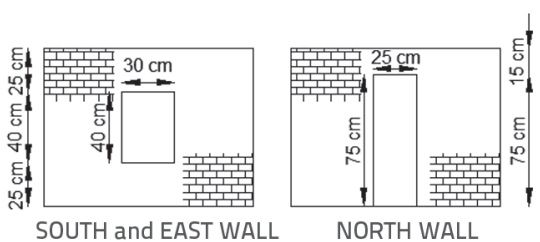

NORTH WALL

Figure 2. Masonry structure geometry used in the experiment

Three types of masonry structures were built as test beds (Table 1). The prepared test specimen is shown in Figure 3. 
Table 1. Masonry structure types

\begin{tabular}{|l|c|c|}
\hline Plaster type & Volume rate [\%] & Specimen \\
\hline Normal & - & $\mathrm{N}$ \\
\hline Polypropylene & $2 \%$ & $\mathrm{P}$ \\
\hline Steel & $3 \%$ & $\mathrm{~S}$ \\
\hline
\end{tabular}
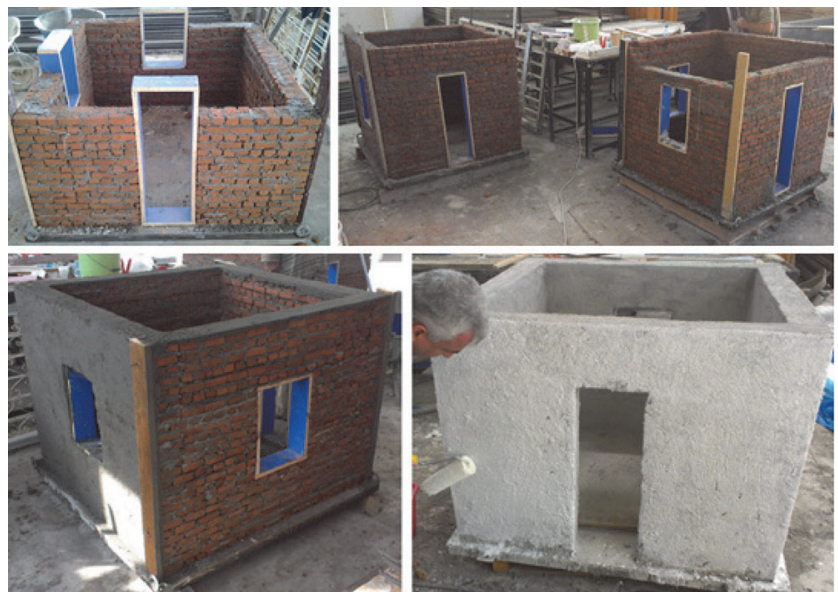

Figure 3. Masonry structure specimens

The Cauchy and Froude law requirements must be satisfied for the real dynamic scaled-model testing on shake table. The Cauchy law is adequate for the phenomenon in which restoring forces are derived from the stress-strain constitutive relationship, while the Froude law applies to cases where gravity forces are important. Thus, both similitude laws must be satisfied for realistic modelling of the linear dynamic response of structures, Sullivan et al. [24]. The simultaneous satisfaction of Cauchy and Froude similitude leads to scale factors presented in Table 2.

Table 2. Scale factors between prototype and model, adapted from Sullivan et al. (2004)

\begin{tabular}{|c|c|c|}
\hline Parameter & Symbol & Scale factor \\
\hline Length & $\mathrm{L}$ & $\mathrm{L}_{\mathrm{p}} / \mathrm{L}_{\mathrm{m}}=\lambda$ \\
\hline Modulus of elasticity & $\mathrm{E}$ & $\mathrm{E}_{\mathrm{p}} / \mathrm{E}_{\mathrm{m}}=1$ \\
\hline Specific mass & $\rho$ & $\rho_{\mathrm{p}} / \rho_{\mathrm{m}}=\lambda^{-1}$ \\
\hline Area & $\mathrm{A}$ & $\lambda^{2}$ \\
\hline Volume & $\mathrm{V}$ & $\lambda^{3}$ \\
\hline Mass & $\mathrm{m}$ & $\lambda^{2}$ \\
\hline Displacement & $\mathrm{d}$ & $\lambda$ \\
\hline Velocity & $\mathrm{v}$ & $\lambda^{1 / 2}$ \\
\hline Acceleration & $\mathrm{a}$ & 1 \\
\hline Weight & $\mathrm{w}$ & $\lambda^{2}$ \\
\hline Force & $\mathrm{F}$ & $\lambda^{2}$ \\
\hline Time & $\mathrm{t}$ & $\lambda^{1 / 2}$ \\
\hline Frequency & $\mathrm{f}$ & $\lambda^{-1 / 2}$ \\
\hline
\end{tabular}

The acceleration scale is the unity, while the time scale is the square root of the geometrical scale $\lambda$. This means that in model the time scale is compressed by the factor $1 / \sqrt{\lambda}$. Therefore, the accelerogram applied to the structure has shorter durations, higher frequency, and the same accelerations. Another important consequence of the similitude law is the increase of the mass of the model relative to the reference prototype.

\subsection{Material parameters for analytical model}

Masonry has a composite structure and this composite consists of two or more different constituent materials. Mechanical characteristics of a masonry panel differ from mechanical properties of individual components. That is why mechanical properties of masonry panels should be determined by experimental testing. Material properties of these masonry panels were obtained by experimental testing and can be found in Basaran et al [25]. The mentioned study investigates behaviour of masonry walls strengthened with reinforced fibre plaster, when subjected to diagonal tensile load. Full blend bricks $100 \times 50 \times 30 \mathrm{~mm}$ in size were used to make masonry walls measuring $400 \times 400 \times 100 \mathrm{~mm}$. Vertical load of $0.1 \mathrm{~mm} / \mathrm{s}$ was applied to samples using a $250 \mathrm{kN}$ hydraulic piston. The load was applied to samples with 450 steel caps. A load cell positioned between the hydraulic piston and steel cap was used to measure the loads. To measure displacement of samples, 5 LVDT devices (linear variable displacement transducers) were positioned both horizontally and vertically on the hydraulic piston, or on either side of the plaster. Data were transferred to a computer using an 8-channel static data acquisition system. The displacement values were established by finding the average of the horizontal LVDT reading values, and the vertical LVDT values. The sliding resistance was obtained by taking the Cos45 value of the load and dividing it by the area. Table 3 shows mechanical properties of the masonry walls specimens. Brick used in the preparation of masonry building had the compressive strength of $2.65 \mathrm{MPa}$, the modulus of elasticity of $125 \mathrm{MPa}$, and the tensile strength of $0.5 \mathrm{MPa}$.

Table 3. Mechanical properties of masonry walls

\begin{tabular}{|c|c|c|c|}
\hline $\begin{array}{c}\text { Specimen } \\
\text { type }\end{array}$ & $\begin{array}{c}\text { Compressive } \\
\text { strength [MPa] }\end{array}$ & $\begin{array}{c}\text { Tensile strength } \\
{[\mathrm{MPa}]}\end{array}$ & $\begin{array}{c}\text { Modulus of elasticity } \\
{[\mathrm{MPa}]}\end{array}$ \\
\hline N & 2,51 & 0,23 & 149 \\
\hline P & 4,26 & 0,43 & 223 \\
\hline S & 3,91 & 0,47 & 270 \\
\hline
\end{tabular}

\subsection{Experimental setup}

The specimen setup is shown in Figure 4. A table measuring $250 \mathrm{~cm} \times 250 \mathrm{~cm}$, and a servo motor with the moving mechanism of $100 \mathrm{kN}$ horizontal force capacity and the displacement capacity of $100 \mathrm{~cm}$, were used in the shaking 
table tests. An accelerometer (biaxial, $\pm 4 \mathrm{~g}$ in capacity), and a $200 \mathrm{~mm}$ potentiometer, were used for measurements. These sensors were connected to 32 channels and 24 bit simultaneous dynamic data acquisition system.

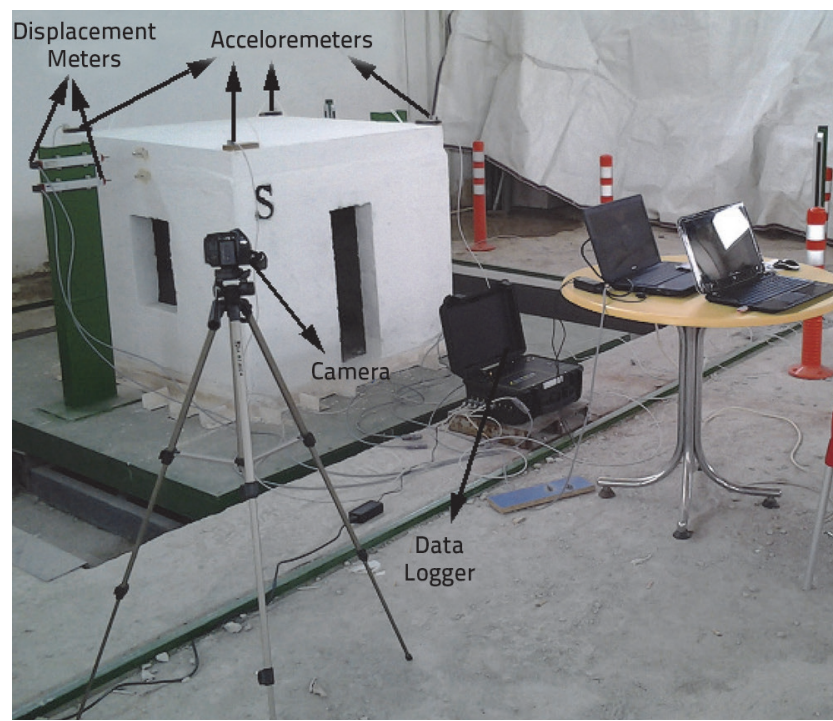

Figure 4. Experimental setup of shaking table

Displacement meters were placed at different levels of the east and west walls, as shown in Figure 4. Biaxial accelerometers were located at different wall levels and on top of the slab, and one was also placed on the shaking table. Four cameras were used to monitor the experiment. The experiment setup diagram is shown in Figure 5.

Simulated cases of severe earthquakes used in the shaking table were obtained from the web site of Peer [26]. Strong earthquakes that caused the loss of life and property in Turkey and worldwide were selected. All records include a maximum ground acceleration of more than $0.3 \mathrm{~g}$. Earthquake parameters are given in Table 3.

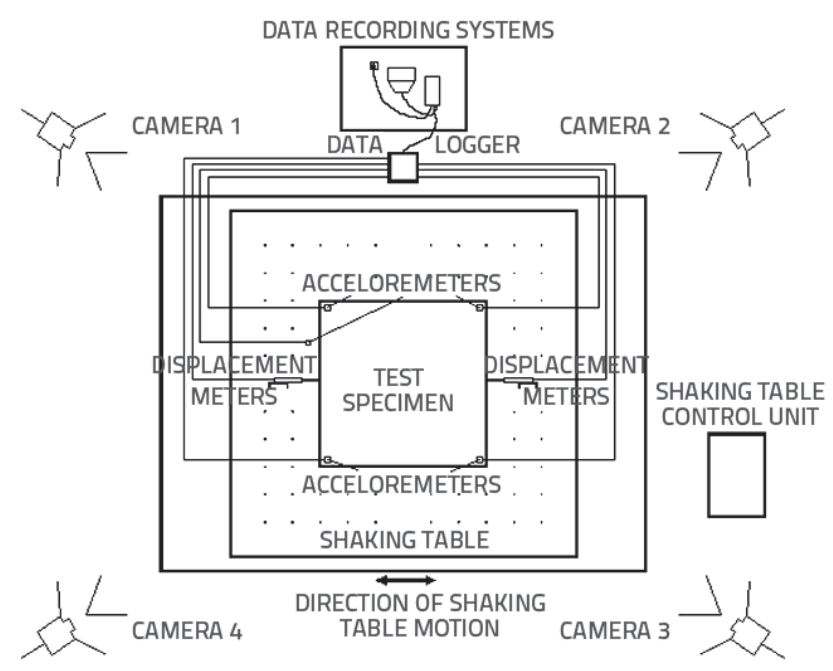

Figure 5. Experiment setup diagram

To conform with the time similitude condition, time history of the original accelerogram was compressed by the factor of $1 / \sqrt{3}$.

\section{System identification}

Values taken from the accelerometers were processed in the DIAdem program [27]. Average acceleration values obtained at corner points of the slab were used in the Fast Fourier Transform (FFT). Fourier Transform graphs were drawn for each specimen $(N, P, S)$ separately, and the FFT graph obtained only for the specimen $\mathrm{S}$ is shown in Figure 6. The FFT graph is filtered by the band-pass process. Acceleration-period graphs were derived from average values of the band-pass filtered graph.

The spectrum graph on which the bandpass filter was used is shown in Figure 7 for specimen S. Peak values of the spectrum graph correspond to natural periods of the specimen S. Bandpass filtered period values for specimens $(N, P, S)$ are shown in Figure 8.

Table 3. Earthquakes used in shaking table experiments.

\begin{tabular}{|c|c|c|c|c|}
\hline Earthquake & Country & $\begin{array}{c}\text { Maximal acceleration } \\
{[\mathrm{g}]}\end{array}$ & $\begin{array}{c}\text { Maximal velocity } \\
{[\mathrm{cm} / \mathrm{s}]}\end{array}$ & $\begin{array}{c}\text { Maximal displacement } \\
{[\mathrm{cm}]}\end{array}$ \\
\hline Düzce & Turkey & 0,535 & 83,5 & 51,59 \\
\hline Erzincan & Turkey & 0,515 & 83,9 & 30,15 \\
\hline Gazlı & Russia & 1,264 & 54,2 & 70,52 \\
\hline Kocaeli & Turkey & 0,376 & 79,5 & 41,18 \\
\hline Loma Prieta & America & 0,563 & 94,8 & 36.92 \\
\hline Tabas & Iran & 0,836 & 97,8 & 31,6 \\
\hline Victoria & Mexico & 0,621 & 34,4 & 13,2 \\
\hline Westmorland & America & 0,496 & 10,89 \\
\hline
\end{tabular}




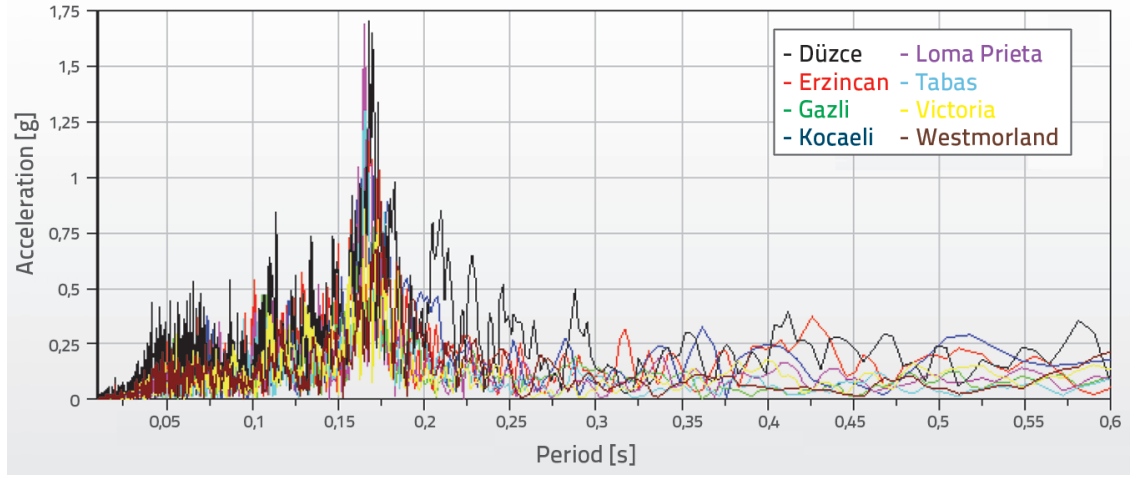

Figure 6. Fourier Transform graph of specimen S

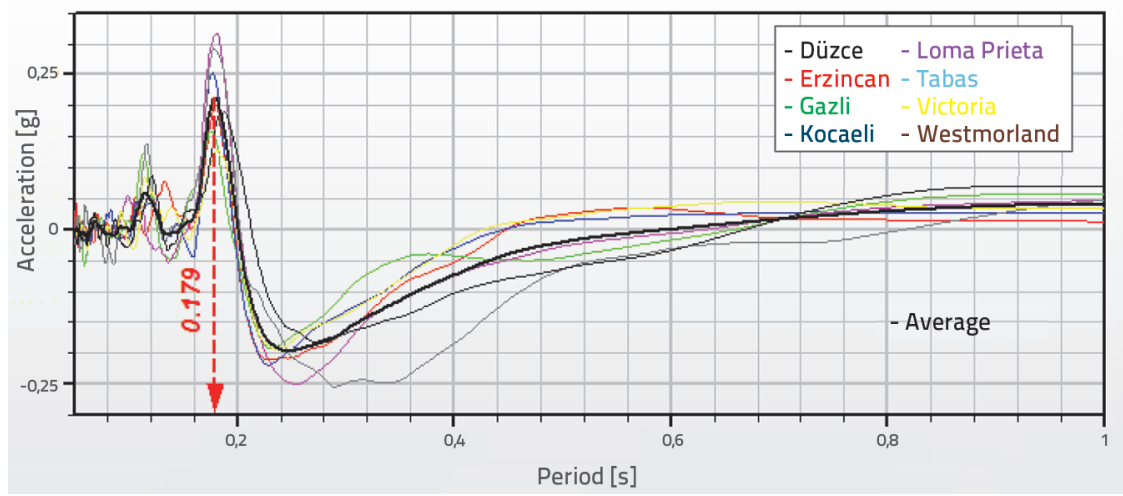

Figure 7. Spectrum graph of band-pass filtered specimen S

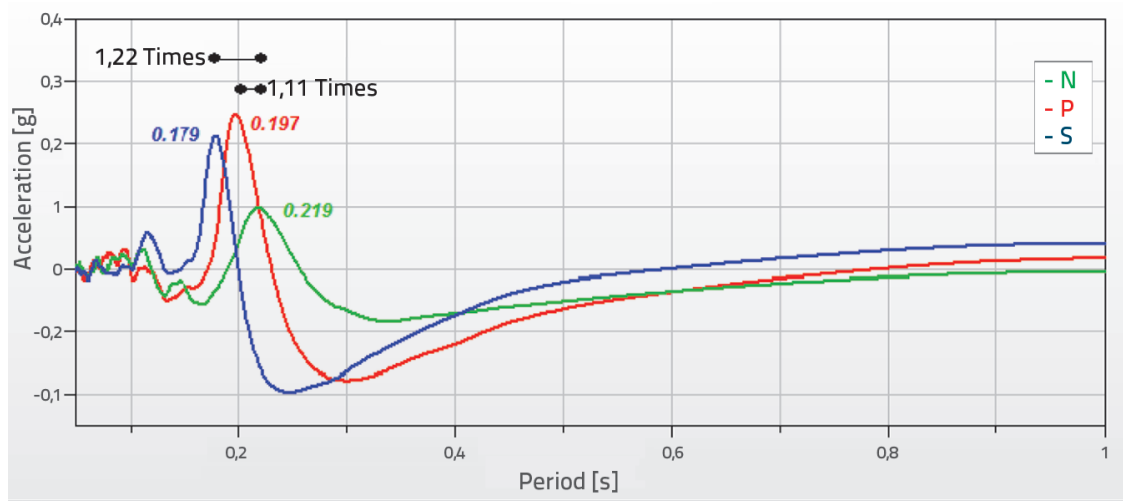

Figure 8. Natural period values of band-pass filtered specimens

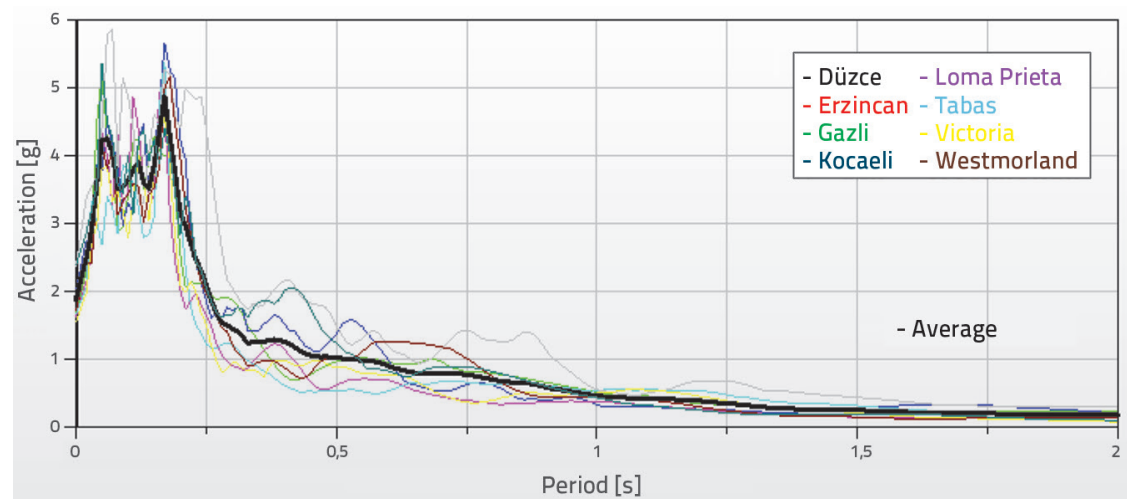

Figure 9. Response spectrum graph of specimen $\mathrm{S}$
Periods of specimens $\mathrm{P}$ and $\mathrm{S}$ are lower than that of the reference specimen $\mathrm{N}$ by $11 \%$ and $22 \%$, respectively. The averaged response acceleration spectrum graph (black line) for the specimen $\mathrm{S}$ is shown in Figure 9, with the response acceleration spectrum graph (coloured line) for each earthquake. Average response acceleration spectra graphs for all specimens are shown in Figure 10.

The highest acceleration value was observed forspecimen S, which isfollowed byspecimens $\mathrm{P}$ and $\mathrm{N}$. Period lengths among peak points may give information about stiffness of the structure. Specimen $\mathrm{S}$ has the highest stiffness, and it is followed by specimens $P$ and $\mathrm{N}$. The first peak acceleration value was detected in 0.06 seconds for specimen $\mathrm{S}$, in 0.09 seconds for $P$, and in 0.1 seconds for $N$. Similarly, the second peak acceleration value was seen in 0.17 second for specimen $S$, in 0.18 second for specimen $\mathrm{P}$, and 0.2 second in specimen $\mathrm{N}$.

Specimen spectrum interaction graphs were obtained in order to explain the relationship between the acceleration and displacement of a specimen, and to make comparisons between reinforced specimens. These graphs were drawn using the following process steps:

- Acceleration spectrum was obtained as a function of period using acceleration values from the experiments.

- Displacementspectrum was obtainedas a function of period using displacement values from the experiment.

- Displacement and acceleration spectrum values corresponding to equal period segments were obtained and ranked.

- Spectrum interaction diagrams were drawn in a way that the displacement spectrum values would be in the horizontal axis and the acceleration spectrum values would be in the vertical axis for each earthquake.

- Averages values of diagrams for eight earthquakes, i.e. filtered linear line spectrum interaction diagrams depicted for the specimen $\mathrm{S}$, are shown in Figure 11 (black line).

- A line was filtered to the average values in the spectrum interaction diagram (black line). The tangents of the lines show stiffness of the structures, as shown in Figure 12. 


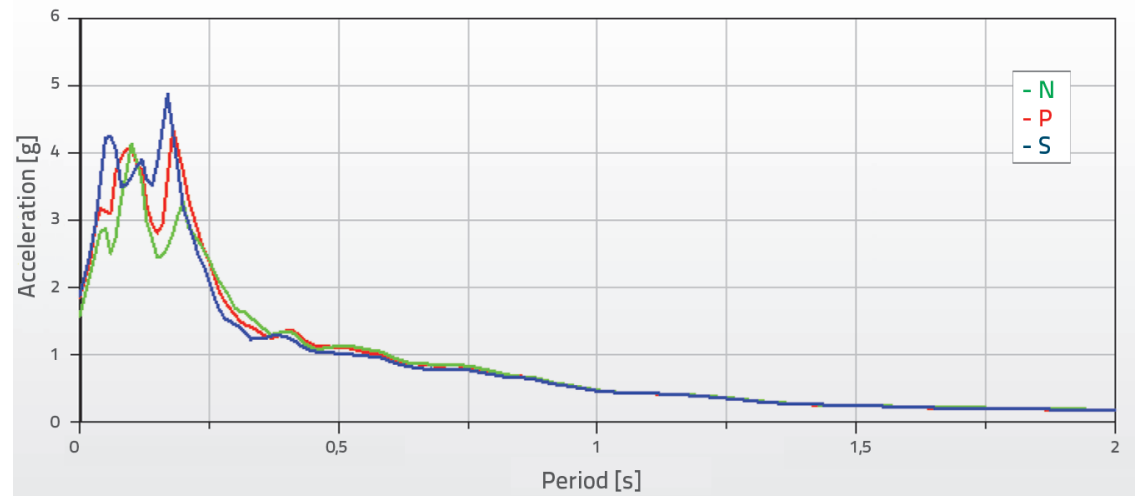

Figure 10. Average response acceleration spectrum graphs for all specimens

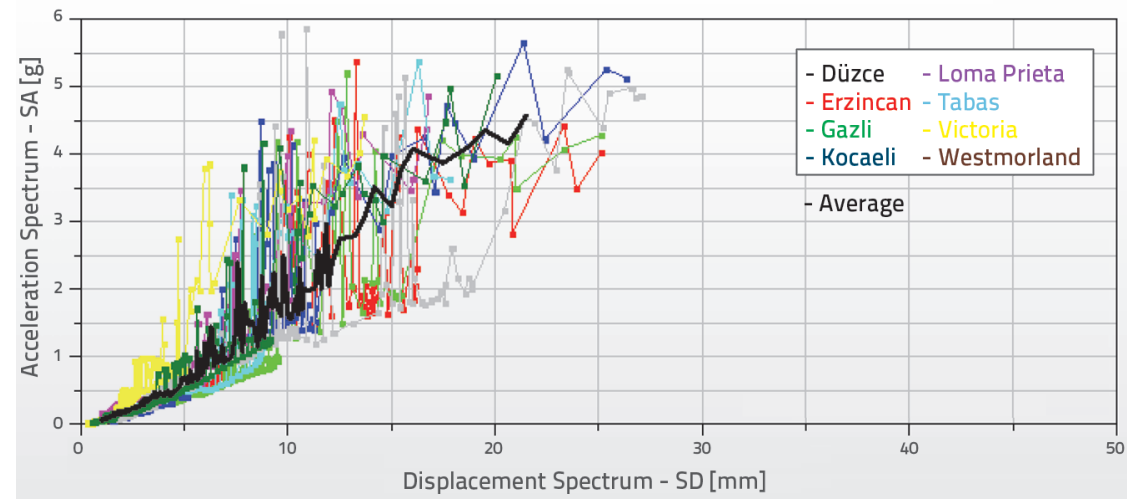

Figure 11. Spectrum interaction diagrams for specimen $\mathrm{S}$

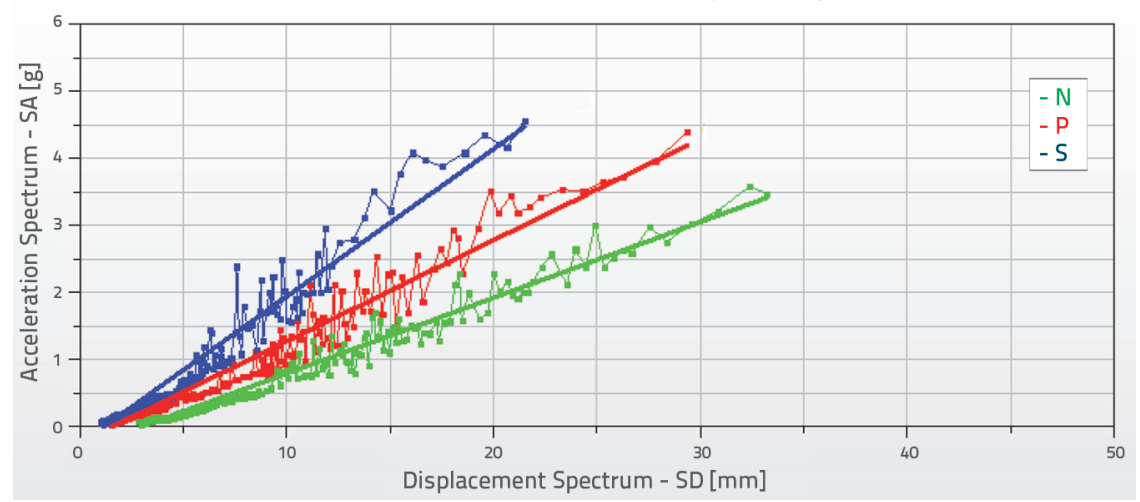

Figure 12. Average spectrum interaction diagrams for all specimens
Spectrum interaction diagrams were generated using the acceleration and displacement values obtained from the time history analysis. Numerical frequencies were also defined using the $\mathrm{FE}$ analysis program.

\subsection{Structure modelling}

The most important step in the finite element analysis of masonry buildings is to model the load-bearing wall elements. In nonlinear analysis of the micro-model of masonry buildings, the number of unknowns is excessively high, which greatly increases the solution-finding time for large-scale system rigidity matrices. To address this problem, several researches have suggested the use of the homogenization method [28]. In this method, a single material property for a wall element formed a brick, mortar and plaster can be obtained using homogenization. Mechanical properties of the model are properties of a composite material made homogeneous [29-31]. In our study, mechanical properties of a composite wall element were obtained using values given in Table 3, and converting them by means of scale factors (assuming $E_{p}$ / $E_{m}=1$, i.e. that the model and prototype have the same material properties). Shell elements were selected as the wall element. The FE model of specimens is shown in Figure 13. The assigned boundary conditions were compatible with the setup. Shaking table accelerations used for experimental studies were taken as the load function in the analysis.

Average spectrum interaction diagrams are given in Figure 12 for the all specimens. As can be seen from this figure, stiffness values can be listed from the lowest to the highest for steel and polypropylene reinforced plaster mortar, and normal plaster mortar.

\section{Finite element model and numerical analysis}

The Finite Element (FE) Analysis program SAP2000 was used in order to compare experiments with the results of numerical analyses. None of specimens subjected to a given load was damaged in the testing. So the linear analysis method was chosen for finding numerical solution for the analysed structures.

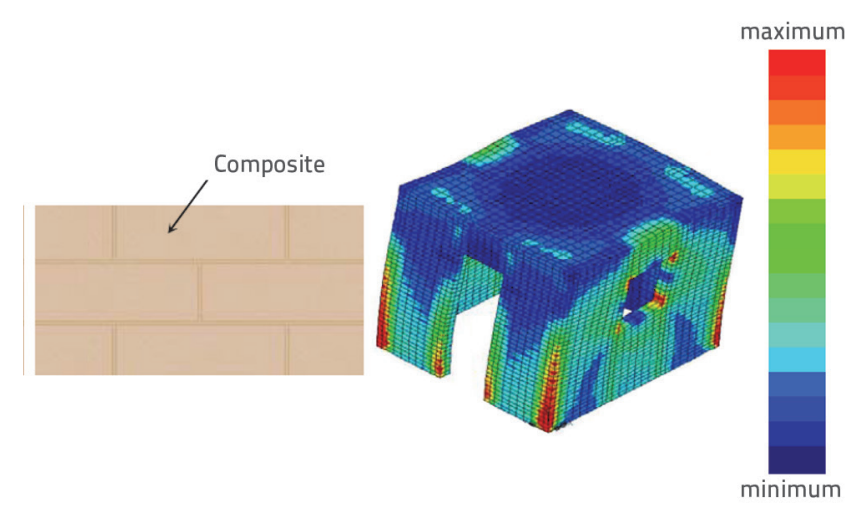

Figure 13. 3D finite element model of specimens in SAP2000 

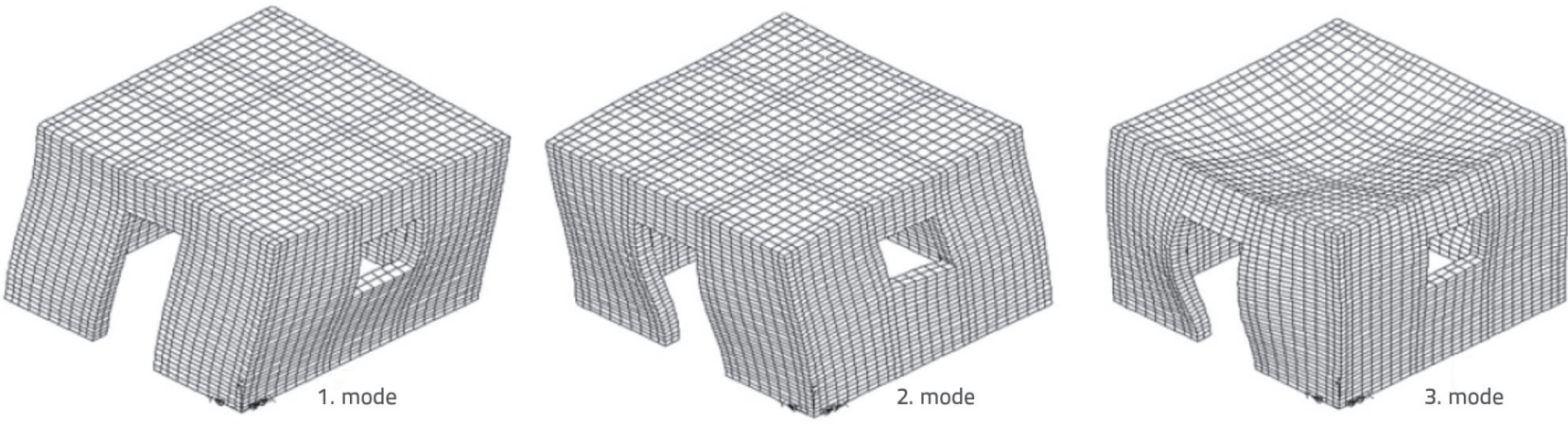

Figure 14. The first three mode shapes

As shown in Table 4, experimental results and numerical results are in harmony.

The first three mode shapes calculated with modal analysis are given in Figure 14. The first mode is the direction in which the rigidity is low.
Table 4. Natural periods by SAP2000

\begin{tabular}{|c|c|c|}
\hline Specimen & Experimental & Numerical \\
\hline N & 0,219 & 0,221 \\
\hline P & 0,197 & 0,209 \\
\hline S & 0,179 & 0,192 \\
\hline
\end{tabular}

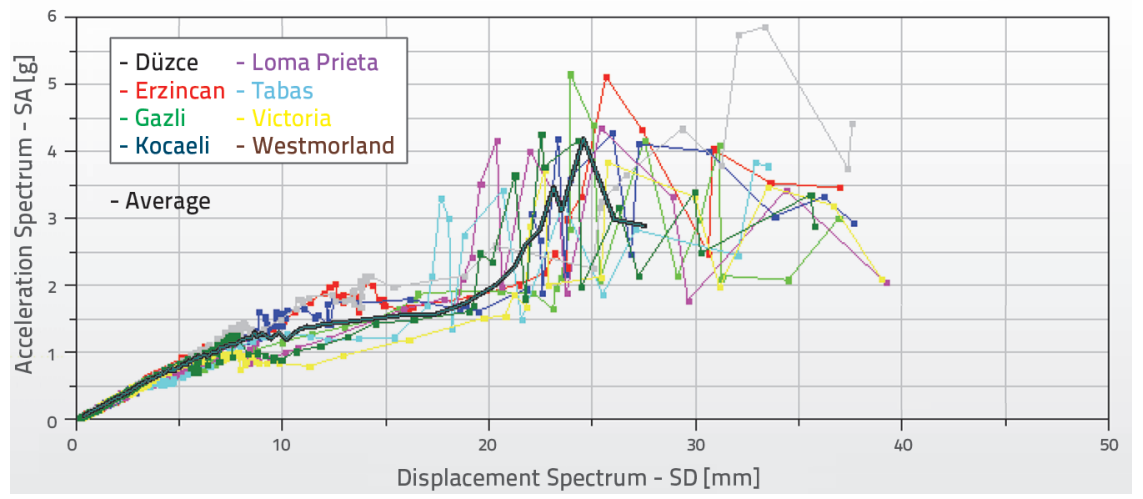

Figure 15. Average spectrum interaction diagrams for specimen S (SAP2000 program)

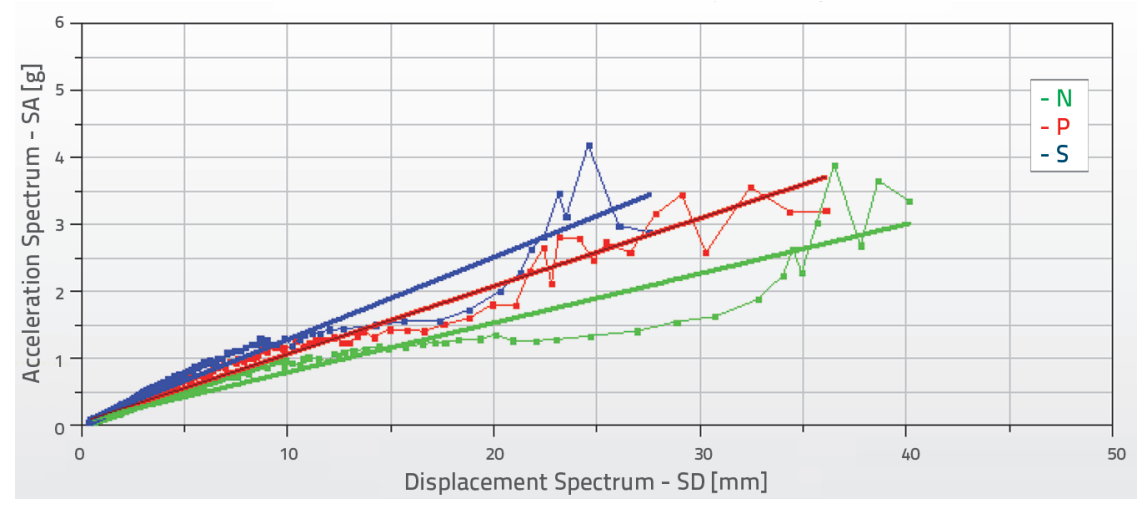

Figure 16. Average spectrum interaction diagrams obtained with SAP2000 program

\subsection{Obtaining the spectrum interaction graphs in computer analysis}

First, the acceleration and displacement results of the structure were obtained using the SAP2000 program. Then the spectrum interaction diagrams were defined.
Acceleration averages of the points in four corners of the floor were used for acceleration values. Averages of the points corresponding to the places where the displacement meters were attached were used for displacement values. Spectrum interaction diagrams obtained from SAP2000 program are given for specimens $\mathrm{S}$ in Figure 15. Average spectrum interaction diagrams for specimens, as obtained from SAP2000 program, are shown in Figure 16. Spectrum interaction ratios obtained experimentally and numerically are given in Figure 17. While a good correlation of experimental and numerical results was achieved for specimens $\mathrm{N}$ and $\mathrm{P}$, a small discrepancy was registered between numerical and experimental values for specimen $\mathrm{S}$.

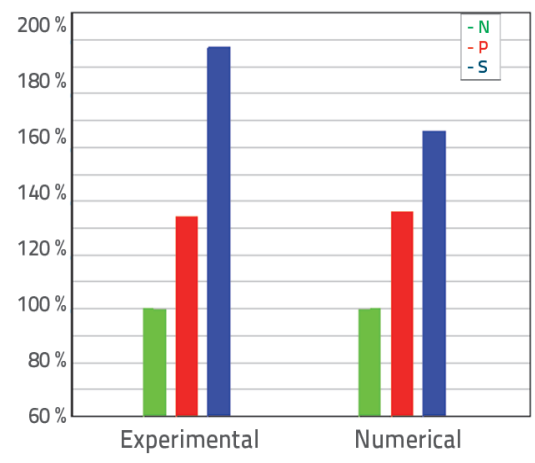

Figure 17. Spectrum interaction rates 


\section{Conclusion}

This study was conducted to determine the seismic behaviour of masonry structures with and without mortar reinforcement. An experimental structural system was set up on the shaking table. Three types of $1 / 3$ scaled model masonry structures were plastered with normal, polypropylene and steel reinforced mortars, and were subjected to severe earthquake action. Seismic behaviour of masonry buildings reinforced with polypropylene and steel fibres was compared to that of traditionally built masonry buildings.

Natural periods were found through Fourier Transform graphs, response acceleration spectrums, and spectrum interactions. Masonry structure periods established with the filtering method, spectrum graphs, and average spectrum interaction graphs, are similar. Periods of specimens $\mathrm{P}$ and $\mathrm{S}$ are lower than that of the reference specimen $\mathrm{N}$ by $11 \%$ and $22 \%$, respectively. Samples with a low natural period are more rigid. Displacements are also lower for rigid specimens. While a good correlation between experimental solutions and numerical solutions based on the SAP2000 program was obtained for specimens $N$ and $P$, a small discrepancy was registered between numerical and experimental values for specimen $\mathrm{S}$.

\section{Acknowledgements}

This study was carried out with the support of the Scientific Research Coordination in Celal Bayar University, in the scope of the project number 2012-47. The authors extend their thanks to the institution for the support given.

\section{REFERENCES}

[1] Korkmaz, H.H., Korkmaz S.Z., Donduren, M.S.: Earthquake hazard and damage on traditional rural structures in Turkey, Natural Hazards and Earth System Sciences, 10, pp. 605-622, 2010.

[2] Döndüren, M.S.: The Effect of wall and cast mortar with improved binding property on the mechanical behaviour of out of plane loaded brick walls, Selcuk University, Graduate. School of Natural and Applied Sci. PhD Thesis, Konya, 2008.

[3] Valluzzi, M.R., Binda, L., Modena, C.: Mechanical Behaviour of Historic Masonry Structures Strengthened by Bed Joints Structural Repointing, Construction and Building Materials, 19, pp. 63-73,

[4] Lucıano, R., Sacco, E.: A Damage Model for Masonry Structures, European Journal of Mechanics, A/Solids, 17-2, pp. 285-303, 1998.

[5] Crisafulli, F.: Seismic Behaviour of Reinforced Structures with Reinforced Masonry Infiills. Phd thesis, University of Canterbury, New Zeland, 1997.

[6] Laurence, P., Rots, J.: Multisurface interface model for analysis of masonry structures. Journal of Engineering Mechanics, 1237, pp. 660-668, 1997.

[7] Lopez, J., Oller, S., Onate, E., Lubliner, J.: Homogenous constitution model for masonry. Intetnational Journal of Numerical Methods in Engineering, 41, pp. 1651-1671, 1999.

[8] Bakir, P.: Instrumentation and system identification of a typical school building in Istanbul, Structural Engineering and Mechanics, 43-2, pp.179-197, 2012.

[9] Bayraktar, A., Coşkun, N., Yalçın, A.: Performance of Masonry Stone Buildings during the March 25 and 28, 2004 Aşkale (Erzurum) Earthquakes in Turkey, Journal of Performance of Constructed Facilities, pp. 21-6, pp. 432-440, 2007.

[10] Bayraktar, A., Coşkun, N., Yalçın, A.: Damages of Masonry Buildings during the July 2, 2004 Doğubayazıt (Ağrı) Earthquake in Turkey, Journal of Engineering Failure Analysis, 14, pp. 147-157, 2007.
[11] Corradi, M., Borri, A., Vignoli, A.: Experimental study on the determination of strength of masonry walls, Construction and Building Materials, 17-5, pp. 325-337, 2003.

[12] Guinea, G. V., Hussein, G., Elices, M., Planas, J.: Micromechanical modeling of brick-masonry fracture, Cement and Concrete Research, 30-5, pp. 731-737, 2000.

[13] Laurence, P., Rots, J.: Multi surface interface model for analysis of masonry structures, Journal of Engineering Mechanical, 1237, pp. 660-668, 1997.

[14] Lee, J. S., Pande, G. N., Middleton, J., Kralj, B.: Numerical modeling of brick masonry panels subject to lateral loadings, Computers and Structures, 61-4, pp. 735-745, 1996.

[15] Lopez, J., Oller, S., Õnate, E., Lubliner, J.: A homogeneous constitutive model for masonry, International Journal for Numerical Methods in Engineering, 46-10, pp. 1651-1671, 1999.

[16] Marfia, S., Sacco, E.: Modeling of reinforced masonry elements, International Journal of Solids and Structures, 38-24-25, pp. 4177-4198, 2001.

[17] Ehsani, M. R., Saadatmanesh, H., Al-Saidy, A.: Shear behavior of URM retrofitted with FRP overlays, Journal of Composites for Construction, 1-1, pp. 17-25, 1997.

[18] Kolsch, H.: Carbon fiber cement matrix (CFCM) overlay system for masonry strengthening, Journal of Composites for Construction, 2-2, pp.105-109, 1998.

[19] Krevaikas, T.D., Triantafillou, T.C.: Computer-aided strengthening of masonry walls using fibre-reinforced polymer strips, Materials and Structures, 38-275, pp. 93-98, 2005

[20] Stratford, T., Pascale, G., Manfroni, O., Bonfiglioli, B.: Shear strengthening masonry panels with sheet glass-fiber reinforced polymer, Journal of Composites for Construction, 8-5, pp. 434443, 2004.

[21] Valluzzi, M. R., Binda, L., Modena, C.: Mechanical behaviour of historic masonry structures strengthened by bed joints structural repointing, Construction and Building Materials, 19-1, pp. 63-73, 2005. 
[22] Kamanlı, M., Donduren, M. S., Cogurcu, M. T., Altın, M.: Experimental study of some masonry-wall coursework material types under horizontal loads and their comparison, Materials and Technology, 45-1, pp. 3-11, 2011.

[23] Lizundia, B., Holmes, W.T., Longstreth, M., Kren, A., Abrams, D. P.: Development of Procedures to Enhance the Performance of Rehabilitated URM Buildings, NIST GCR 97-724-1, 1997.

[24] Sullivan, T., Pinho, P., Pavese, A.: An introduction to structural testing techniques in earthquake engineering. Educational Report IUSS Press (ROSE 2004/01). Pavia, Italy, 2004.

[25] Başaran, H., Demir, A., Bagci, M.: The Behavior of Masonry Walls with Reinforced Plaster Mortar, Advances in Materials Science and Engineering, Article ID 436946, 2013. (doi. $\operatorname{org} / 10.1155 / 2013 / 436946)$
[26] The Pacific Earthquake Engineering Research Center (PEER), University of California, Berkeley, U.S.A.

[27] DIAdem, National Instruments Ireland Resources Limited.

[28] Lourenço, P. B.: Computational Strategies for Masonry Structures. Delft, PhD Thesis, Netherland, 1996.

[29] Cecchi, A., Milani, G., Tralli, A.: Validation of Analytical Multiparameter Homogenization Models for Outof plane Loaded Masonry Walls by Means of the Finite Element Method., Journal of Engineering Mechanics, pp. 185-198, 2005.

[30] Sab, K.: Yield Design of Thin Periodic Plates by a Homogenization Technique an Application to Masonry Walls, Comptes Rendus Mécanique, 331-9, pp. 641-646, 2003.

[31] Anthoine, A.: Homogenization of Periodic Masonry: Plane Stress, Generalized Plane Strain or 3D Modeling, Communications in Numerical Methods in Engineering, 13, pp. 319-326, 1997. 